\title{
Human as the protector of creation
}

\section{[Clovek jako ochrance stvoreni]}

\author{
Eva Vymetalova Hrabakova - Peter Kondrla - Vera K. Vlasova - Svetlana \\ V. Dmitrichenkova - Olga V. Pashanova
}

DOI: 10.18355/XL.2020.13.03.02

\begin{abstract}
The biblical vision focuses on several different concepts of the role of humanity in the world. The authors concentrate on a model of the biblical myth of Adam, who is charged with ruling over other creatures and protecting them from danger. This model, which comes from the older mythical fabric of the ancient Near East, is then transformed both theologically and ethically in a Hellenistic era. It is from the end of the Hellenistic period that the New Testament texts about Adam and Christ appear. The article continues to focus on the shape of the human-creature relationship, focusing on the current world and the social problems created by the insufficient protection of the world. The subsequent challenges come from biblical paradigms: humanity as protector, wise housekeeper and caretaker. The authors work with particular regard to the Christian paradigms, but they will also mention in passing the current models in force in Judaism and Islam.
\end{abstract}

Key words: humanity, biblical concept, responsibility, Adam and Christ

\begin{abstract}
Abstrakt
Biblická vize se zaměřuje na několik různých konceptů role lidstva ve světě. Autoři se soustředí na model biblického mýtu Adama, který je pověřen ovládáním jiných tvorů a jejich ochranou před nebezpečím. Tento model, který pochází ze starší mýtické struktury starověkého Blízkého východu, je pak teologicky i eticky přeměněn $v$ helenistickou éru. Novozákonní texty o Adamovi a Kristu se objevují od konce helénistického období. Článek se nadále zaměřuje na podobu vztahu člověk-stvoření, zaměřuje se na současný svět a sociální problémy způsobené nedostatečnou ochranou světa. Následující výzvy přicházejí z biblických paradigmat: lidstva jako ochránce, moudrého hospodyně a domovníka. Autoři pracují se zvláštním zřetelem na křest’anská paradigma, ale zmíní se také o současných modelů platných v judaismu a islámu.
\end{abstract}

Klíčové slová: lidstvo, biblický concept, odpovědnost, Adam a Kristus

\section{Úvod}

„Co je člověk, že na něho pamatuješ... “ (Ps 8,5) v této době postmoderny či tekuté modernity (Petrusek, 2010: 801)? Člověk je homo sapiens sapiens, bytost, která je nadaná rozumem a na základě zkušenosti s okolním světem ví o své konečnosti. Člověk je zároveň živý tvor, který hledá a utváří smysl své vlastní existence, podílí se na smyslu společnosti a leccos soudí o řádu prrírody, planety i naší galaxie. Charakterizovat člověka a vymezit jeho úlohu nebo funkci ve světě můžeme $\mathrm{z}$ tolika hledisek, kolik si lidstvo vytvořilo obor; a v každém z nich hraje člověk nějakou roli. Speciální a dle našeho soudu finalizující a integrální roli hraje člověk v teologickém jazykovém i etickém diskursu. Ten vychází z mýtického jazyka a uvádí nás do prostředí prvních smyslových projevů, zvuků a barev. Do ráje, který se v naší dimenzi existence poněkud ztrácí, ale po němž stále toužíme. 


\section{Mýtus o člověku v ugaritské staroorientální literatuře}

Rajský př́iběh je jedním z nejstarších př́iběhů starověkého Předního východu a právě $\mathrm{v}$ něm nacházíme antropogonický mýtus čili adamovský př́běh, tedy vyprávění o původu a významu člověka ve stvoření. Na pozadí tohoto mnohovrstevného mýtického textu se nám rýsuje prastará sumerská i akkadská látka, prrípadně západosemitské mýty, jež jedinečným způsobem krystalizují v biblické tradici. S ohledem na současné bádání však nesmíme zapomínat, že variace adamovského mýtu $\mathrm{v}$ různých částech Bible pochází z mladší doby, než zmiňované látky. V nich se archaické východosemitské a západosemitské obrazy stvoření světa a člověka doplňuji znalostmi z řecké mytologie a helénistického světa a myšlení.

V Hebrejské bibli nalézáme několik stěžejních textů, které př́iběh o rajském člověku rozvádějí, byt' každý z nich trochu jinak. Na prvním místě připomeňme Genesis (Gen 2-3). Lidské potomstvo se v návaznosti na sumerskou terminologii $L U$ či přsesněji AWILU - bytost, která v sobě nese krev boha WE, se představuje jako ADAM - ze země ,,adama“/ dam/ -,,krev, což je prapůvodně kompozitní stvoření, analogicky k většině živočichů rozlišené jako iš we iša „muž a žena“. Toto je celistvá reprezentace lidského rodu, která je pověrena Hospodinem Bohem stvořený svět $\mathrm{v}$ horizontu ráje obdělávat a střežit. Na ADAMA, který dostává tak velký úkol, jímž de facto zpř́tomňuje selem elohim „obraz Boha“ doráží božská či spíš polobožská postava nachaš (Had). Podoba dorážejícího a svádějícího hada má však kořeny v kenaanské tradici (Korpel - De Moor, 2014: 1-14). Co má však do činění $\mathrm{s}$ člověkem a vůbec $\mathrm{s}$ lidským pokolením? Jeden $\mathrm{z}$ dešifrovacích kódů nám nabízí ugaritské mýtické texty. V několika $\mathrm{z}$ nich se objevuje Choron, hadí božstvo $\mathrm{s}$ ambivalentním charakterem. Choron podobně jako pozdější biblický nachaš se představuje v pozici rebelujícího božstva, jehož obdoby najdeme ve foinické, egyptské, hebrejské i řecké literatuře. Místem jeho zvýšené působnosti je syrská poušt’ a dá se říci, že mu některé texty připisují zodpovědnost za vulkanické procesy. Choron otravuje strom života, který se stává od této chvíle lidstvu nebezpečným. Biblický text sděluje, že člověk se svou družkou si mají podmaňovat vše živé a panovat nad ním $(G e n 1,28)$. Především však mají svěřené stvoření střežit , ̌̌s-m-r “a chránit před nebezpečím. Orožený had „Cerastes“ je však poněkud zvláštní stvoření, který si př́lišnou péči a pozornost nezaslouží. Člověk je však jeho chováním fascinovaný a přinejmenším k němu zaujímá ambivalentní vztah. Víme, že nachaš se i v biblické tradici ocitá na pomezí mezi božským a lidským. Je nadán mimořádnou vychytralostí, ví mnohé a s informacemi dovede účelově nakládat, v podstatě ve svůj prospěch. Bouří se vůči Stvořiteli a patrně mu závidí jeho láskyplný zájem o člověka. „Proměňuje“ doslova jedem otravuje a transformuje sumerský kosmický strom života, na strom poznání dobrého a zlého, přičemž poznávací aspekt mimořádně posiluje. Činí z něj tedy ve skutečnosti strom smrti. Takto tedy jedná bytost mimořádným způsobem spjatá se zemí. V ugaritské ikonografii již z období 2000 př. n. 1. se však navíc odhaluje Choronova astrální stránka a i díky této staré semitské tradici se později prezentuje jako Hilal či pozdější turecký Aldebaran. Ve své astrální úloze představuje dominantní symbol noční oblohy. Jeho obvyklým epitetem je Iblís, pozdějši pojmenování d’ábla $\mathrm{v}$ islámské tradici. Intertextualita mezi ugaritskými zdroji a spisy Hebrejské bible nám mnohé napoví. V ugaritských rituálních textech je totiž zmiňován jeho vztah ke kolektivní božské reprezentaci Kušaratu, patronkyním dobrého porodu a mateřství. Takto nepř́mo je vyjádřen i vztah $\mathrm{k}$ Evě, která je v Bibli označována za matku všech živých. Díky jiným staroorietálním textům odhalíme, že Eva není jen žena číslo jedna, její jméno odkazuje na mateřskou bohyni Kubabu, pozdější syrskou Kybele. Choron tedy ve své fyziognomii disponuje s prostředky, kterými umí Evu ovlivnit. Chava em ,, matka Chava/Živa“ nese rysy mateřské bohyně plodnosti, proto je pro hada - zemské božstvo - tak dostupná. Pozemská stránka Choronovy identity je velmi výrazná, nebot' je v několika mýticko-rituálních ugaritských textech spojován s vinnou révou, paradoxně představující rostlinu smrti a 
opětného oživení. Rituální destrukcí vinné révy, jejím rozmělněním a vypitím dochází k symbolické destrukci smrti a nového života.

Choronovi v hadí podobě však překvapivě nechybí ani aquatická symbolika, odhalující jeho počáteční chaotické principy, a to ve vztažnosti s ugaritským Baalem a jeho partnerkou bohyní Anat, kdy jako vodní had ohrožuje obtížně nastolený rád ve světě prŕrody i lidstva.

Je tedy zřejmé, že svůdce v podobě oroženého hada může vystupovat $\mathrm{z}$ vod, působit na zemi i padat z nebes. Mutuje podle prostředí, do něhož se dostane a v mýtickém světě- zdá se - nemá konkurenci. Naprosto nevyzpytatelně vstupuje člověku do cesty a znesnadňuje mu péči o stvoření a zodpovědnou vládu nad světem. Jobův prríběh je toho nesporným důkazem.

„Jak jsi spadl z nebe, třpytivá hvězdo, jitřenky synu!“ (Isa 14,12). Zde se d’ábel „Hilel ben Šachar" vyjevuje v osobě babylónského panovníka, jehož pýcha dojde dne zúčtování. Je to syn personifikované jitřenky a večernice, „nositel světla“ možná též únosce světleného aspektu z nebes. Ugaritský ,antihrdina“ Choron, rebelující či dokonce poštvávající proti stvořiteli, otci bohů a lidí Elovi přechází do biblického ráje a aspiruje na velmi podobnou úlohu, vymezující se vůči Hospodinu. Touží proměnit si ADAMA i podle své podoby a vůle. Adamovský mýtus a jeho výklady v biblické, intertestamentální, křestanské, judaistické i islámské tradici ukazují součinnost i souboj člověka s touto protivící se entitou.

Na pochybení prvotního Adama pak poukazuje též 28. kapitola knihy Ezechiel, kde je jeho pád či přímo vpád do tohoto světa přenesen na pád týrského krále. I to je důsledek chtivé a částečně i zvídavé spolupráce s oroženým hadem. „Byl jsi věrným obrazem pravzoru, plný moudrosti a dokonale krásný. Byl jsi v Edenu, zahradě Boži... “ (Ezek 28,12b-13a). Chotem tachnit je zřejmě podoba stvořitelského pravzoru prvotního ADAMA. Obraz nehodných králů v biblickém textu je výkladem adamovského mýtu, který sděluje, jak může být díky spolupráci s d’áblem adam poničen. Stává se z něj zvrhlá karikatura dobrého stvoření člověka. Na určité úrovni pochopení tohoto mýtu je tak kladena velká podobnost mezi Adamem a Králem. Získává od stvořitele schopnost podmaňovat, vládnout ale i střežit, ba dokonce opatrovat. Výkonná vláda nad světem i pečování a ochrana veškerého stvoření jsou z pohledu Stvořitele neoddělitelné veličiny. Ďábel se rozhodl povýšit vládu a prosazení moci nad ochranu stvoření. Úkolem ADAMA je však integrace obou důrazů.

\section{Biblické pojmy - jejich výklad a funkce}

V Hebrejské bibli, knize B $\mathrm{B}^{e}$ rešit „Na počátku“ (Gen 1,26-27) čteme o stvoření ADAMA jako selem "socha či idol" a podle $d^{e} m u t$,podoby/esence“" boha. Někteří badatelé se snaží tyto pojmy vysvětlit do současnému př́jemci této zprávy a soudí, že výraz selem opisuje reprezentaci božství v lidském tvoru, zatímco pojem demut odkazuje na bytostný, dalo by se ř́ci dokonce genetický vztah mezi stvořitelem a člověkem, takový jako je mezi otcem a synem (Roubalova - Kralik - Slivka - Tavilla, 2018). Metafora genetického kódu, který zkoumají př́rodní vědy je krásně zakomponována v biblickém hebrejském jazyce (Crouch, 2010: 10). Dekódovaní genetické šifry se děje pomocí dalšího textu z knihy B ${ }^{e}$ rešit (Gen 5, 1-3), kde je týchž výrazů užito pro zplození Adamova syna Seta. Oba texty tak implicitně naznačují tajemství, tak jako je Adam Setovým otcem je Hospodin Bůh rodičem lidstva. Touto organickou metaforou z rodinných vztahů se vlastně vysvětluje vztah Boha k lidskému rodu (Crouch, 2010:14). Otisk božství či nevědomá sounáležitost s Bohem je pak součástí přirozeného zákona, který na rozdíl od zákona zjeveného židům, křest’anům a muslimům je zřejmý i všem ostatním lidem. Součástí tohoto přirozeného zákona je závazek člověka vůči stvoření. Někdy se v souvislosti s tímto závazkem mluví o Adamově smlouvě, která je přístupná veškerému lidstvu. Součástí tohoto

XLinguae, Volume 13 Issue 3, June 2020, ISSN 1337-8384, ISSN 2453-711X 
přirozeného zákona je správa a ochrana stvoření. Jak vyváženě spravovat, ochočovat, usměrňovat př́rodu a neztroskotat u dvojího úskalí bájné Skylly a Charibdy. Skylla totiž může přinutit člověka, aby zodpovědnou péči o všechny př́írodní prvky a zdroje proměnil v idolatrii a začal vědomě uctívat stvoření místo stvořitele. To je jeden extrém, který vede do záhuby. Druhým nebezpečím, tedy naší Charibdou, je selhání v úloze ochránce a pečovatele. Člověk může místo rozumného zacházení přírodu využívat a zneužívat. I tento směr vede $\mathrm{k}$ zániku přírody a posléze člověka uprostřed ní.

\subsection{Starý a nový Adam}

Př́iběh o ADAMOVI pokračuje i za hranicemi kanonizace Hebrejské bible v intertestamentální literatuře třeba v př́běhu „Vita Adae“, v midraších a Talmudu a posléze i v Koránu. Je tedy zřejmé, že byl inspirací pro řadu novozákonních spisů, z nichž nejvýrazněji se o ADAMOVI - správci starého světa a KRISTU - správci nového světa dočteme $\mathrm{v}$ listu Ř́manům, poměrně komplikovaném teologickém traktátu a také ve svébytném Janově evangeliu. Autoři i př́ípadní redaktoři obou novozákonních spisů byli pravděpodobně dobře obeznámeni s Tanachem, Septuagintou a patrně i se stř́pky intertestamentální literatury své doby. Adam v návaznosti na raný judaismus uvádí, že první ADAM byl psyché dzoé „živá duše“/ nefeš hajja v hebrejštině/ a druhý ADAM - KRISTUS tó pneuma dzopoiún „duch oživující“/ruah hajja; hajjim v hebrejštině/. Duch propojuje duši s tělem a je jejich součástí. Zatímco první člověk $\mathrm{z}$ hlediska Pavlovy typologie představoval korporativní osobnost, veškeré lidstvo starého světa i věku, Kristus představuje nové lidství, tedy veškerý lidský rod nového světa i věku. Vedle Adama hraje i pro Pavlovu interpretaci významnou úlohu Eva, která je v typologii přirovnávána ke Kristově matce Marii (Dunning, 2014: 90). Typologické drama, vylíčené v listu Římanům, ukazuje na úlohu člověka ve stvoření před branami ráje v oboustranném provozu. První ADAM odešel z ráje, druhý ADAM směřuje do ráje. Stvoření má svoji korunu ve své vlastní záchraně. Pavel adresátům naznačuje, že díky Ježíši Kristu jsme dál a máme cestu do rajského modu existence vyznačenou. Člověk jako součást ADAMA má možnost Ježíše následovat a zasazovat se o dobré zacházení se stvořením. Sám Pavel přiznává, že i když tu možnost má, tak to nečiní, protože starý ADAM se v něm bouří (Rom 5-7).

Někteří teologové pozorují záměrnou provázanost mezi Ježíšem na kř́ži a hrobem v zahradě v Janově evangeliu (John 19, 23-41) s narativem z knihy B ${ }^{e}$ rešit $(\mathrm{Gn} 2,8$ 25), kde se píše o tom, že Hospodin uspal, přivedl mrákoty na Adama (Chen 10). Smrt a spánek se zdají synonymy, které dodnes používáme v krásné literatuře, zejména v poezii. Další ilustrací myšlenky o Adamovi a jeho vztahu k Evě je v Janově evangeliu alegorický text o svatbě v Káni Galilejské. Podobně jako v B rešit (Gen 2, 24) se pojednává o přechodovém rituálu vstupu do manželství i tady se záměrně využívá svatba k tomu, aby se druhý Adam Kristus představil jako ženich, který opouští matku a stává se ženichem a králem své komunity (církve) (Chen 10).

\subsection{Postava Adama v judaismu}

Pro judaismus je lidské bytí výsledkem Božího rozvažování a volby. Do prrírody je člověk Bohem uveden, což znamená, že vztah člověka k přírodě je vlastně zprostředkovaný. Právě proto, že neseme Boží obraz, máme osobnost, která nás od zbytku prírody odděluje. Boží obraz pak podle judaismu naplňujeme dvojím způsobem, jednak podobností, jednak funkcí. Taková byla ve starověku pozice krále (Mittleman, 2015: 51). Je hodně zajímavé, že vlastně tím, jak se Adam společně s Evou stávají rodiči, dostávají se do rolí spolustvořitelů ve vlastním teritoriu, čili na zemi. S fyzickou podobností jdou ruku v ruce i vrozené etické dispozice. Po přestupku, který je podaný $\mathrm{v}$ mýtickém př́iběhu z ráje, už člověk nezobrazuje Boha chotem tachnit, ale stále má možnost Boha napodobovat. To znamená, v okrsku své 
působnosti má člověk odpovědně zacházet se stvořením, udržovat ho, zušlecht'ovat a rozvíjet. Člověk se na rozdíl od ostatních živých tvorů a vůbec veškeré př́rody pohybuje $\mathrm{v}$ rámci morálních paradigmat, která ho vybavují vědomím odpovědnosti a charakteru. V tomto smyslu je nahlíženo i plození potomstva, které není biologickým aktem per se, nýbrž důkazem odpovědného př́stupu, péče a rozvoje nového života. (Mittleman, 2015: 57). Už podle biblických textů je zjevné, že člověk má sklon ke zlému, jako důsledek vůle k přežití, ale protože má zároveň svobodu volby, může navzdory sklonu nakonec zvolit dobré. Tím, že člověk ,, $r-d-h$ “ „vládne“, tak biblická hebrejština i hebrejština pozdější pěkně jazykově vyjadřuje lidské vybavení k udržení života na planetě v rovnováze. Člověk má dbát na vyváženost mezi živočišnými druhy (Gen 8,12$)$, čímž bude poukazovat na Boží vládu nad světem. Na příběhu Kaina a Abela je vidět, že člověk se rodí divoký a nespoutaný, se sklonem k hněvu a zášti. Cvičením $\mathrm{v}$ dobrotě se však jako dobrý pastýř stává oprávněným vládcem nad živočichy (Mittleman, 2015: 62). V judaismu existuje výklad, podle něhož si Kain špatně vyložil předpoklad. Viděl, že Hospodin přijal Abelovu obět' zvířete, a tak se domníval, že je prrípustné zabíjení lidí, protože ti také patří k živočichům (Mittleman, 2015: 62). Naopak, na př́kladu již výše zmiňovaného hada ale také býka z Ex21,28, že živočichové mohou způsobit lidský rozklad. Připodobňování člověka ke zvířatům je podle židovského práva nesprávné a nemorální (Mittleman, 2015: 62). Člověk má živočichy chránit a usměrňovat $\mathrm{v}$ jejich existenci, aby pokud možno nepřesáhli jeho kompetence a možnosti konání. Na rozdíl od ostatní přírody se člověk pohybuje v oblasti morálního diskursu, je schopen vyvozovat správné závěry ze špatného jednání, poučit se z nich a být odpovědný za svá rozhodnutí. Podle judaismu má člověk tř́i základní složky osobnosti - nefeš elan vital(zdraví); nešama (poznání, kognitivní schopnosti); ruah vášeň (energii). Osobnost se celý život dotváŕí ve vztahu ke světu, ostatním lidem a samozřejmě ve vztahu k Bohu (Mittleman, 2015: 62). Potomci Kainovi se podle biblické zprávy rozplodili, založili města a zahájili proces civilizace zemského povrchu. Spolu s civilizací a pokrokem se též začala šírit agrese a boj o přežití mezi lidskými rody. Tak je tomu i v biblickém narativu o Lámechovi (Gen 4, 23-24). Bůh však člověku stále nabízí možnost nápravy, která se děje v rituálu tešuva „opětný návrat, obrácení, pokání“. Jedině takto je možno vrátit se do blízkosti Hospodina, dárce života a krále světa. Pozoruhodné je pak z hlediska judaismu i lidské zrcadlení Hospodinovy správy nad světem. U člověka je zhodnotitelné jeho zdraví, síla a krása. Morální danosti tříbí a zdokonaluje ve společenském kontaktu a jedná dobře $\mathrm{s}$ ohledem na to, co přijde. Jde mu o zachování člověka v př́rodě. Judaismus podobně jako křest'anství rozvíjí téma eschatologické, podle něhož je způsob lidského jednání důležitý také s ohledem na olam haba „,pricházející svět či věk“. V biblické a pobiblické tradici se však dočteme, že Bůh naplňuje jiné hodnoty, v nichž výrazným způsobem figuruje láska $\mathrm{k}$ lidstvu, soud a spravedlnost (Exod 33,18-19). Člověk celou svou bytostí, charakterem a jednáním ukazuje k e svému Stvořiteli. Jeho úkolem je pečovat o prŕrodu na této planetě a nedělat mu ,špatnou reklamu“ (Gen 47,9).

\subsection{Motivy v islámu}

K islámskému zpracování adamovského mýtu se dostaneme opět díky intertextualitě přes intertestamentální a mimobibiblickou literaturu, z nichž nemůžeme opominout Knihu Jubileí, výše zmiňovaný midraš Genesis Raba, knihy o Adamovi a palestinské targúmy (překlady a výklady do aramejštiny) Chumaše (Pěti knih Mojžíových). Velkou pozornost si však zaslouží především pojednání označované jako Jeskyně pokladů, jež je reflektováno v Koránu i další mimokoránské literatuře, včetně hadíthú (komentářù). (Mikulicova, 2014: 134). Na rozdíl od judaismu je pojem Adam vysvětlován jako vlastní jméno rodiče, z něhož povstalo veškeré lidstvo. Boží podoba, vzezření, která je podle biblické a intertestamentální tradice samozrrejmá, se v Koránu

XLinguae, Volume 13 Issue 3, June 2020, ISSN 1337-8384, ISSN 2453-711X 
již interpretuje jinak, nebot' člověk nemůže nést v sobě obraz Boha. O to víc je vak zdůrazněno, že jeho úkolem je dbát o Boží právo ve světě, nebot' je chalifa fil ard (/Boží/zástupce na zemi) (Korán 2,30). Korán uvádí čtyři přednosti, kterými Bůh obdařil člověka, a jež ho předřazují ostatní prrírodě i andělưm. Člověk byl stvořen Boží rukou, obdržel dech Boží, Bůh ho naučil jména celého stvoření a dokonce nařídil andělům, aby se Adamovi poklonili (Mikulicova, 2014: 138). V islámské tradici je právě tajemství pojmenování všech tvorů znamením, že Adam je vládce nad živými i prorokem. Rozumem a řečí je schopen prírodu řídit a vymezovat hranice živých bytostí. Mýtický ráj je skutečností, která se poměrně v masivní podobě promítá do islámské eschatologie. Člověk opustil ráj, protože neposlechl Boha, jako věřící muslim však do ráje opět nalezne cestu (Mikulicova, 2014: 143). V Koránu a následné tradici se pozornost zaměřuje na poznání sexuální, víc než intelektuální a z něj nutnost dodržovat morální pravidla ve společnosti. Lidské provinění v podobě komunikace člověka s Iblísem je možné napravit poslušností vůči Bohu. Bůh po vyhnání z ráje člověka vede, což dokládají proroci, poslové a v posledu samotná kniha Korán. Milosrdenství Boží je také nejvýraznější atribut, kterým Bůh působí na člověka. $S$ ohledem na tento atribut má člověk nad stvořením rovněž milosrdně panovat. V jistém smyslu obdobně jako je v křest'anství protipólem a naplněním Adamovy úlohy druhý Adam - Kristus, tak je i v Koránu uveden prorok Muhammad jako osobnost, naplňující odkaz Adamův (Mikulicova, 2014: 151).

\section{3. Člověk jako ochránce, dobrý hospodář a správce stvoření - etické důsledky a závazky}

Z výše uvedených písemných zdrojů a kolektivní paměti minulých civilizací i současných národů můžeme postulovat několik etických tvrzení.

\section{1 Člověk je ve světě jako ochránce stvoření}

Krásnou a dodnes působivou metaforou je příměr člověka k pastýři, který pečuje, živí, napájí, ošetřuje a hlídá svěřené stádo. Člověk má ochraňovat přírodu která tvoří horizont jeho současné existence. Člověk má ctít přirozený zákon morálky, který se vyznačuje tím, ,co nás udržuje při životě, bráni anarchii a rozkladu společnosti, ale $i$ tím, co nás uči štastnému a spokojenému soužití s ostatními lidmi “ (Vogel, 2011: 128). Lidství odpovídá přirozenému zákonu a jho kvalita se projevuje a poměřuje vztahy, které člověk uskutečňuje ve vztahu k jiným lidem i ostatním živým tvorům na planetě. Správnou podobu těchto vztahů charakterizuje odpovědnost člověka vůči člověku i okolní prrírodě a služba pro zachování a rozvoj života (Laudato $\mathrm{Si}, 2015$ ). Člověk jako služebník, který má službu uprostřed stvoření, neustále bojuje s různými projevy a nápory zla ve společnosti i v prírodě. To je jeho stěžejní úkol ve světě. Svět není objektem, který člověk používá dle své libovůle. Odpovědnost se váže k jeho skutkům, k tomu, co s př́rodou činí (Zalec - Pavlikova, 2019 a,b).

\section{2 Člověk jako dobrý hospodář}

Další prŕípadnou metaforou je obraz dobrého hospodáře, který rozumně nakládá se svým stvořením, aby měl užitek, a přitom stvoření zachoval i pro budoucí potomstvo. Je to přirozená vloha, kterou může udusit touha po rychlém a plynulém zisku na úkor ostatních. Papežská encyklika Laudato $\mathrm{Si}$, podobně jako prohlášení dalších křest’anských církví, se zamýšlí nad tím, jaký svět zanecháme našim dětem. V jaké podobě a stavu jim předáme národní i světové hospodářství v nejširším smyslu tohoto slova. V papežské encyklice je např́klad položena otázka: „Co je smyslem života na zemi, jaké jsou hodnoty a základy společenského života, co je cílem naši práce a veškerého úsili " (Laudato Si, 2015: 160). Velkým nebezpečím se stalo uchvácení moci, jež získal na základě technických výdobytků. Člověk začíná být nahrazován strojem a přestává plnit svou pracovní funkci. Člověk začíná být nahrazován strojem a přestává plnit svou pracovní funkci. Objevují se lidská povolání, která jsou již nyní 
dostatečně kvalitně i lépe nahrazena stroji, ale i zdánlivě „,neužitečný člověk“ má právo na dobrý život. Takto komplexně je třeba řešit nápravu záležitostí ve světě, který je naším domovem. Při př́ležitosti letošního významného výročí J. A. Komenského nelze nezmínit ani jeho pokusy ve „Všeobecné poradě o nápravě věcí lidských“, jež jsou do určité míry sice dobově podmíněné, avšak ve vztahu k přírodě nadčasové. Především dobrou výchovou se lidé mohou učit dobře hospodařit na zemi a rozumně i efektivně nakládat se svěřeným bohatstvím. Takový pohled si však žádá $i$ nové pochopení náboženství a jeho místa v životě člověka.

Podobně jako u Komenského i v dalších výzvách pozorujeme, že zájem o přírodu je složkou integrovaného systému zájmu o člověka v jakékoliv životní situaci. Celý svět je totiž organismem, v němž je vše vzájemně propojeno a provázáno. Moudrý hospodáŕ rozpoznává znamení doby a vyvozuje z něj potřebná rozhodnutí.

\section{3 Člověk jako správce stvoření}

Vláda nad světem je tím nejnáročnějším a zdánlivě nejlákavějším privilegiem lidského rodu. Rozvíjející se antropocentrismus vak upřednostňuje člověka za všech okolností a narušuje jeho skutečný vztah ke světu. Touha po moci v něm probouzí agresivitu starých biblických narativů, zdánlivě mocný a silný člověk může zvrhle rozhodnout o zneužívání dětí, opuštění starých lidí, obchodování s lidmi a zvířaty, které mají právo na život a jak říká Bible, na život v plnosti. Neutěšený vztah k př́ŕrodě, vede však recipročně i k zhoršení kvality vlastního života. Do nekonečna se nemůže mocný člověk nebo mocná společnost či národ ukrývat za svými hranicemi, „check pointy“ svých měst a domů. Domovem je totiž celá planeta, a když se jí člověk nebude moci otevrrít a propojit se i s tím nejskrytějším koutem vzdálené prŕírody, nebude št'astný a pochopitelně nebude nad př́rodou ani dobře vládnout. Bez vlastní reflexe, pokory a tešuvy (pokání) člověk nemůže být dobrým správcem stvoření. To není možné bez pochopení vlastní identity v kontextu morální odpovědnosti (Martin et al., 2020).

\section{Závěr}

Na základě výše uvedených analýz, reflexí a úvah je zřejmé, že člověk povstal jako bytost korunující stvoření. Podle náboženských tradic má přírodu integrovat a v kvalitní podobě předvádět Stvořiteli. Na základě vlastních vloh o to může usilovat, ale nedosáhne výsledku bez spolupráce s ostatními lidmi a pochopitelně bez vědomí svého přesahu a vztahu k Bohu. Takový je pohled nábožensky ukotveného člověka, který jej nabízí i všem ostatním, jež mají vědomí přirozeného zákona vetknuté do své genetické výbavy. V opačném príípadě je sám člověk v ohrožení.

\section{Acknowledgement}

This article was published with the support of the Slovak Research and Development Agency under the contract No. APVV-17-0158.

The work is performed according to the Russian Government Program of Competitive Growth of Kazan Federal University.

The publication was prepared with the support of the "RUDN University Program 5$100 "$ ".

The work is performed according to the project of improving competitiveness of the leading Russian universities among the leading world scientific education centers "5100"of I M Sechenov First Moscow State Medical University (Sechenov university).

\section{Bibliographic references}

BEN ISAIAH, A. - SHARFMAN, B. 1977. The Pentateuch and Rashi's Commentary. New York: Brooklyn Publishing Company. 
BIBLE, Pismo svate Stareho a Noveho zakona vcetne deuterokanonickych knih. 1991. Cesky ekumenicky preklad. Praha: Zvon.

CROUCH, C. L. 2010. Genesis1, 26-27 a Statement of humanity's divine parentage. In: The Journal of Theological Studies (New Series), vol. 61, n. 1, pp. 1-15.

DUNNING, B.H. 2014. Christ Without Adam, Columbia: Columbia University Press. ISBN 978-02-3116-765-9.

HIRSCH, I. - SICHER, G. 1985. Pět knih Mojžíšových. Praha/New York: Appeal of Conscience Foundation.

CHEN, S. 2016. The Marriage and Wedding Imagery of Jesus and Adam: The Intertextual Connection of John 19,23-37 and Genesis 2,18-25. Melbourne: Pilgrim Theological College.

JERUZALEMSKA BIBLE. 1995. Pentateuch. Praha: Krystal. ISBN 80-85929-07-4. KORPEL, M.C.A. - de MOOR, J.C. 2014. Adam, Eve and the Devil. Amsterdam: Protestant Theological University. Available online: https://www.bibleinterp.com/PDFs/Paper_Korpel_De_Moor.pdf (cit. 26. 3. 2020)

MIKULICOVA, M. 2014. Adam. Příběh prvního člověka v knize Genesis a v Koránu. In Theologica, vol. 4, n. 1, pp. 133-151. ISSN ISSN 1804-5588.

MITTLEMAN, A. L. 2015. Human Nature and Jewish Thought: Judaism's Case for Why Humans Matter. Princeton: Princeton University Press. ISBN 978-06-9114-9479.

NEUSNER, J. (ed.). 1988. The Mishnah. A New Translation. Yale: University Press. ISBN 0-300-050022-4.

LAUDATO SI. 2015. Encyklika Svatého Otce Františka o péči o společný domov. Libreria editrice Vaticana, překlad Česká biskupská konference. ISBN 978-80-7450194-7

PETRUSEK, M. 2010. Zygmunt Bauman: „tropika diskursu“ slovo o pop-kulture a spotrebni spolecnosti epochy „tekute modernity“. In: Sociologicky casopis (Praha), vol. 46, n. 5, pp. 801-820. ISSN 0038-0288.

SIDON, E. (trans.) 2012. Pet knih Mojzisovych vcetne haftarot s ceskym prekladem rabina Efraima Sidona. Praha: Sefer. ISBN 978-80-85924-67-1.

RAHLFS, A. (ed.). 1979. Septuaginta. Stuttgart: Deutsche Bibelgesellschaft.

RABINOVITCH, M. (ed.). 2006. The Mishnah. New York: Mesorah Publications, Ltd.

ROUBALOVA, M. - KRALIK, R. - SLIVKA, D. - TAVILLA, I. 2018. The significance of bringing first fruits of the land into Jerusalem temple: A historicaltheological perspective. In: Historia Ecclesiastica, vol. 9, n. 1, pp. 3-13. ISSN 13384341 .

THEODOR, J. - ALBECK, CH. 1965. Midrash Bereshit Rabba. Critical Edition with Notes and Commentary. Jerusalem: Wahrmann Books.

VOGEL, J. 2011. Prirozeny zakon a otazka univerzalni etiky v Cirkvi ceskoslovenske husitske. In: Studia theologica, vol. 46, n. 4, pp. 127-131.

VZNESENY KORAN. 1972. [Arabic original: al-Quran]. I. Hrbek (transl.). Available online: www.vzdelavaci-institut.info/?q=system/files/Koran.pdf

ZALEC, B. - PAVLIKOVA, M. 2019a. Religious tolerance and intolerance. In: European Journal of Science and Theology, vol. 15, n. 5, pp. 39-48. ISSN 1841-0464.

ZALEC, B. - PAVLIKOVA, M. 2019b. Civic virtues and functions of religion in public life. In: European Journal of Science and Theology, vol. 15, n. 6, pp. 75-84. ISSN 1841-0464.

Words: 4689

Characters: 31212 (17,34 standard pages)

ThDr. Eva Vymětalová Hrabáková, Th.D.

Hussite Theological Faculty Charles University in Prague 
Pacovská 350/4,

14000 Praha

Czech Republic

eva.vymetalova@htf.cuni.cz

Doc. Dr. Peter Kondrla, PhD.

Faculty of Arts,

Constantine the Philosopher University in Nitra,

Hodzova 1

94901 Nitra

Slovakia

pkondrla@ukf.sk

Prof. Vera K. Vlasova

Deputy Director for Educational Activities of the Institute of Psychology and Education,

Kazan (Volga region) Federal University

18 Kremlyovskaya Str.

420008, Kazan

Russian Federation

v2ko@mail.ru

Assoc. Prof. Svetlana V. Dmitrichenkova

Head of the Department of Foreign Languages of Academy of Engineering,

Peoples' Friendship University of Russia (RUDN University)

6 Miklukho-Malkaya Str.

117198, Moscow

Russian Federation

sw.wl@mail.ru

Assoc. Prof. Olga V. Pashanova

Department of Organization and Economics of Pharmacy,

I.M. Sechenov First Moscow State Medical University (Sechenov University)

8 Trubetskaya Str.

119991, Moscow

Russian Federation

ov-pashanova@yandex.ru 